\title{
SCREENING FOR EXOPOLYSACCHARIDE-PRODUCING BACTERIA FROM SUB-TROPICAL POLLUTED GROUNDWATER
}

\author{
FUSCONI, R. ${ }^{1}$ and GODINHO, M. J. L. ${ }^{2}$ \\ ${ }^{1}$ Universidade Federal de Uberlândia, Instituto de Biologia, Av. Engenheiro Diniz, 1178, C.P. 593, \\ CEP 38401-136, Uberlândia, MG, Brazil \\ ${ }^{2}$ Universidade Federal de São Carlos, Departamento de Ecologia e Biologia Evolutiva, \\ Via Washington Luís, Km 235, CEP 13565-905, São Carlos, SP, Brazil \\ Correspondence to: Mirna J. L. Godinho, Universidade Federal de São Carlos, Departamento de Ecologia e \\ Biologia Evolutiva, Via Washington Luís, Km 235, CEP 13565-905, São Carlos, SP, Brazil, \\ e-mail: godinho@power.ufscar.br \\ Received July 16, 2001 - Accepted September 14, 2001 - Distributed May 31, 2002
}

(With 1 figure )

\begin{abstract}
A selection of exopolysaccharide (EPS) - producing bacterial strains was conducted in groundwater adjacent to an old controlled landfill in the City of São Carlos (São Paulo, Brazil). The strains were isolated in $\mathrm{P}$ and $\mathrm{E}$ media under aerobic and microaerophilic conditions at $25^{\circ} \mathrm{C}$. A total of 26 strains were isolated and based on the mucoid mode of the colonies, 6 were selected and their morphological, physiological and biochemical aspects were characterized. All strains presented pigmentation, ranging from yellow to orange and from pink to salmon, with a shiny glistening aspect in all tested media. Strains Lb, Lc and Lg, which excelled the others with regard to the mucoid mode of the colonies, were selected to be cultured in E medium with alternate sucrose and glucose as carbon sources in anaerobiosis at $25^{\circ} \mathrm{C}$ to analyze the production of EPS. Strains Lc and Lg were classified as being of order Actinomycelates, suborder Corynebacterineae. Lg strain was identified as Gordonia polyisoprenivorans and Lc strain did not correspond to a known description and therefore a more detailed study is under preparation. Considering all ecological aspects and the metabolic potential associated with the microorganisms of the environment studied, as well as the capacity to produce pigment and EPS, and the presence of G. polyisoprenivorans, a rubber degrader bacterium, the potential of the groundwater analyzed is evident as a source of microorganisms to be utilized in studies related to environmental remediation.
\end{abstract}

Key words: bacteria, exopolysaccharide, groundwater, landfill.

\section{RESUMO}

\section{Seleção de bactérias produtoras de exopolissacarídeos de águas subterrâneas contaminadas de ambiente subtropical}

Foi realizada a seleção de linhagens bacterianas produtoras de exopolissacarídeos (EPS) de águas subterrâneas adjacentes ao antigo aterro controlado da cidade de São Carlos (São Paulo, Brasil). O isolamento foi realizado nos meio $\mathrm{P}$ e $\mathrm{E}$ em condições de aerobiose e microaerofilia a $25^{\circ} \mathrm{C}$. Foram isoladas 26 linhagens e, com base na mucosidade das colônias, 6 foram escolhidas e caracterizadas quanto a aspectos morfológicos, fisiológicos e bioquímicos. As colônias das linhagens apresentaram aspecto brilhante em todos os meios testados, com pigmentação variando de amarela a laranja e de rosa a salmão. As linhagens Lb, Lc e Lg, que se destacaram das demais pela mucosidade das colônias, foram selecionadas para cultivo em meio E suplementado alternadamente com glicose e sacarose como fonte de carbono, em anaerobiose a $25^{\circ} \mathrm{C}$, para a verificação da produção de EPS. As linhagens Lc e Lg foram classificadas como sendo da ordem Actinomycetales, subordem Corynebacterineae. A 
linhagem Lg foi identificada como Gordonia polyisoprenivorans e a linhagen Lc não correspondeu a nenhum gênero descrito e, portanto, novas investigações estão em andamento. Considerando os aspectos ecológicos e o potencial metabólico associados aos microrganismos do ambiente estudado, como a capacidade de produzir pigmento e EPS, e a presença de Gordonia polyisoprenivorans, bactéria degradadora de borracha, fica evidente o potencial das águas subterrâneas em questão como fonte de microrganismos a serem utilizados em processos de remediação ambiental.

Palavras-chave: bactéria, exopolissacarídeos, águas subterrâneas, aterro controlado.

\section{INTRODUCTION}

Programs search for naturally occurring microorganisms that have better pollutant degradation kinetics, attack a wider range of pollutant compounds, and do so over a broader range of microbial conditions, are attempting to expand the range of microorganisms used for bioremediation of contaminated sites (Atlas, 1995).

Although technical difficulties in sampling the subsurface environments have long limited the ecology study of groundwater and until recently, most people thought that these environments were virtually sterile (Gibert et al., 1994), there is no longer doubt that a large number and diversity of viable organisms exist in the subsurface and that their metabolic activities contribute to the cycling of energy and materials in this environment (Fliermans \& Balkwill, 1989; Butler et al., 1997). Screening programs of the subsurface environment showed that groundwater bacteria are potentially able to degrade many natural and xenobiotic compounds such as pesticides, fertilizers, and industrial chemicals which can reach aquifers making these microorganisms attractive to in situ bioremediation (Gounot, 1994). However, if we are to utilize in situ bioremediation, more basic research is needed to better characterize the microbial populations and activities in the subsurface (Gounot, 1994; Zheng \& Kellogg, 1994).

On solid surfaces exposed to aqueous environments bacterial growth is seen as biofilms in which the microbial cells are associated with large amounts of exopolysaccharides (EPS) (Sutherland, 1990). Exopolysaccharides are essencial to the biological success of most bacteria living within the biofilm in the varied natural environments in which they are observed since they can concentrate nutrients from water flow and protect the bacteria from antibacterial agents and from predators (Costerton, 1985). The EPS investigations are in an increasing demand since the biofilm degradative communities can be used for in situ bioremediation of contaminated sites (Lappin-Scott \& Costerton, 1992).

Studies conducted on the old landfill in the town of São Carlos (SP, Brazil) revealed the presence of a pollution plume (Ellert et al., 1990) as well as the presence of an abundant microflora dominated by bacterial populations (Fusconi \& Godinho, 1999). This paper deals with a search for indigenous exopolysaccharide-producing bacterial strains with potential usage in bioremediation programs through biofilms.

\section{MATERIAL AND METHODS}

\section{Strains isolation and maintenance}

The sampling for bacterial isolation from groundwater in the area of the old landfill of São Carlos (located in the recharge area for the Guarani aquifer) was carried out according to Fusconi \& Godinho (1999).

The heterotrophic bacterial strains were isolated at $25^{\circ} \mathrm{C}$ under aerobic and microaerophilic conditions in $\mathbf{P}$ medium (g/L) (Kölbel-Boelke et al., 1988): peptone, 1.0; glucose, 0.1; $\mathrm{K}_{2} \mathrm{HPO}_{4 \mathrm{x}}$ $3 \mathrm{H}_{2} \mathrm{O}, 0.1 ; \mathrm{FeSO}_{4} \times 7 \mathrm{H}_{2} 0,0.02$; and in $\mathbf{E}$ medium (Clark et al., 1981): a) basic medium (g/960 mL): $\mathrm{KH}_{2} \mathrm{PO}_{4}, 2.7 ; \mathrm{K}_{2} \mathrm{HPO}_{4}, 13.9$; yeast extract, 0.5 ; b) solution 1: $10 \%$ sucrose; c) solution 2 (Wolin solution) (g/L): EDTA, $0.5 ; \mathrm{MgSO}_{4} \times 7 \mathrm{H}_{2} \mathrm{O}, 6.14$; $\mathrm{MnSO}_{4} \times \mathrm{H}_{2} \mathrm{O}, 0.56 ; \mathrm{NaCl}, 1.0 ; \mathrm{CaCl}_{2} \times 2 \mathrm{H}_{2} \mathrm{O}$, $0.12 ; \mathrm{ZnSO}_{4}, 0.1 ; \mathrm{FeSO}_{4} \times 7 \mathrm{H}_{2} \mathrm{O}, 0.18 ; \mathrm{CuSO}_{4} \times$ $5 \mathrm{H}_{2} \mathrm{O}, 0.02 ; \mathrm{AlK}\left(\mathrm{SO}_{4}\right)_{2} \times 12 \mathrm{H}_{2} \mathrm{O}, 0.02 ; \mathrm{Na}_{2} \mathrm{MoO}_{4} \times$ $2 \mathrm{H}_{2} \mathrm{O}, 0.01 ; \mathrm{H}_{3} \mathrm{BO}_{3}, 0.01 ; \mathrm{Na}_{2} \mathrm{SeO}_{3}, 0.007 ; \mathrm{NiCl}_{2}$, 0.002 ; d) solution $3: 10 \%\left(\mathrm{NH}_{4}\right)_{2} \mathrm{SO}_{4}$; e) solution 4: $5 \% \mathrm{MgSO}_{4}$ solution. The solutions were autoclaved separately and added aseptically in the indicated order, $10 \mathrm{ml} / \mathrm{L}$ each, to the basic medium. Microaerophilic conditions were produced by a combination of iron and sodium bicarbonate (Jurgensen, 1981), and the $\mathrm{pH}$ of both media was 
7.0. After a maximum period of incubation of 7 days. The colonies were picked at random and replated for purification onto the respective media. Isolated strains were stored on nutrient agar at $4^{\circ} \mathrm{C}$.

\section{Selection of exopolysaccharide-producing bacteria}

The selection of EPS-producing bacterial strains involved 5 steps:

Step 1: Strains whose colonies were found to be more mucoid in the isolation media ( $\mathrm{P}$ and E media) were chosen. Step 2: The selected strains were phenotypically characterized according to Murray et al. (1994) and Smibert \& Krieg (1994), involving the following tests: colonies and cells morphology, pigment production on nutrient agar, $\mathrm{P}$ medium, E medium and 50\% BHA medium (Difco), catalase activity, acid production from glucose, relationship to oxygen, presence of spores and growth on different culture media $(50 \%$ BHI, 50\% BHA, solid E medium and solid and liquid $\mathrm{P}$ medium). The growth on liquid media was analyzed under aerobic and anaerobic conditions. For the anaerobic growth $\mathrm{NaNO}_{3}(1 \mathrm{~g} / \mathrm{L})$ was added as the final electron acceptor and the atmosphere was exchanged through bubbling with nitrogen gas for $1 \mathrm{~h}$ for each liter of culture medium. Step 3: The strains were cultured in anaerobiosis, in media, which contributed to the production of EPS ( $\mathrm{E}$ and BHA 50\%). The production of EPS was identified with Alcian blue 8GX staining (Murray et al., 1994) of cells from $40 \mathrm{~h}$ cultures on E medium under aerobic and anaerobic conditions. Another scree- ning was performed based on the mucoid mode of colonies (Chan et al., 1984) and EPS production. Step 4: The three strains, selected in step 3, were cultured in anaerobiosis at $25^{\circ} \mathrm{C}$ in a refrigerated orbital shaker (100 rpm). E medium was used with alternate, sucrose and glucose as carbon sources. According to Linton (1990) and Sutherland (1990), EPS production is affected by the cultivation conditions (i.e. substrate). The bacteria were cultured in $100 \mathrm{ml}$ flasks, containing $50 \mathrm{ml}$ of culture medium and $5 \%$ inoculum. Samples $(2.5 \mathrm{ml})$ were taken during the cultivation for optical density determination and the production of EPS during the stationary phase was analyzed as described in step 3. Strains which exhibited better results relating to the mucoid mode pattern in solid medium and growth in E medium with at least one carbon source were selected. Step 5: Selected EPS-producing bacterial strains were identified by phylogenetic analysis at the Fundação Tropical de Pesquisas e Tecnologia André Tosello (Campinas, SP) and were stored for further investigations.

\section{RESULTS}

A total of 26 bacterial strains were isolated from groundwater samples in the landfill area of São Carlos City.

In step 1, 6 isolated bacterial strains with mucoid colonies were chosen ( $\mathrm{La}, \mathrm{Lb}, \mathrm{Lc}, \mathrm{Lf}, \mathrm{Lg}$ and $\mathrm{Lh}$ ) and the microbial characteristics are summarized in Table 1.

TABLE 1

Microbial characteristics of bacterial strains isolated from polluted groundwater.

\begin{tabular}{|c|c|c|c|c|c|c|}
\hline \multirow{2}{*}{ Strain } & \multirow{2}{*}{ Cell morphology } & \multirow{2}{*}{ Cell size $(\mu \mathrm{m})$} & \multirow{2}{*}{ Gram staining } & \multirow{2}{*}{$\begin{array}{c}\text { Catalase } \\
\text { activity }\end{array}$} & \multicolumn{2}{|c|}{ Acid production with glucose } \\
\hline & & & & & Aerobiosis & Anaerobiosis \\
\hline $\mathrm{La}$ & coccobacillus & $1.0 \times 2.4$ & - & + & $\mathrm{D}$ & + \\
\hline $\mathrm{Lb}$ & coccobacillus & $0.8 \times 2.1$ & - & + & + & + \\
\hline $\mathrm{Lc}$ & pleomorphic & $1.0 \times 3.0$ & + & + & - & + \\
\hline $\mathrm{Lf}$ & rod & $0.4 \times 2.2$ & - & + & - & + \\
\hline $\mathrm{Lg}$ & pleomorphic & $1.0 \times 2.4$ & + & + & $\mathrm{D}$ & + \\
\hline $\mathrm{Lh}$ & rod & $0.7 \times 2.2$ & - & + & - & + \\
\hline
\end{tabular}

D: dubious; +: positive; -: negative. 
The cells from strains $\mathrm{La}$ and $\mathrm{Lb}$ were coccobacillus and from strains Lf and Lh were rods; the strains Lc and Lg were pleomorphic and predominantly arranged in clusters while the other strains were isolated or paired cells. The results of the physiological and biochemical tests showed the absence of sporulating bacteria, the presence of facultative anaerobic metabolism and positive catalase activity in all strains. Only Lb bacteria produced acid in the presence and absence of oxygen. Acid production by the remaining strains occurred only under anaerobiosis. All strains presented pigmentation, ranging from yellow to orange and from pink to salmon, with a shiny glistening surface aspect in all tested media. La, Lb, Lc and Lg strains showed physiological versatility growing in all media and under all conditions under which they were tested (data not shown).

In step 3 production of EPS was observed in all strains, except La. The development of a mucoid aspect, indicating a possible EPS development by the strains, was more evident in strains $\mathrm{Lb}$ and $\mathrm{Lc}$ when cultured on E and 50\% BHA media, and in strain Lg when cultured on E medium.

Due to the mucoid mode, strains Lb, Lc and Lg were selected and cultured in E medium supplemented with glucose or sucrose (step 4). The three selected strains grew with both carbon sources, being the highest optical density observed in $\mathrm{Lg}$ strain cultured in E medium with sucrose (OD = 1.185) and in E medium with glucose $(\mathrm{OD}=1.170)$, followed by Lc strain cultured in E medium with glucose $(\mathrm{OD}=0.792)$. The lowest growth was observed in Lc strain cultured in E medium with sucrose (OD = 0.200) (Fig. 1). The growth of Lc strain in E medium with glucose, considering the highest optical density obtained, was approximately four times higher than in E medium with sucrose. The production of EPS, tested with Alcian Blue, was positive for all tested strains and with both carbon sources (Table 2).

Lc and Lg strains, which exhibited better results relating to the mucoid mode pattern in solid medium and growth in E medium with at least one carbon source, were classified as being of order Actinomycetales, suborder Corynebacterineae. Lg strain was identified as Gordonia polyisoprenivorans and Lc strain did not correspond to a known bacterial description and therefore a more detailed study is under preparation.

\section{DISCUSSION}

The selection process of EPS-producing bacterial strains was fundamentally based on the development of mucoid aspect of strain colonies. This characteristic, according to Chan et al. (1984) and Junkins \& Doyle (1992), who studied the production of EPS, respectively by Pseudomonas aeruginosa and enterohemorrhagic Escherichia coli, indicates a high production of EPS bacterial strains. Other studies in which the development of the mucoid mode was related to EPS production by bacteria have also been detected on Pseudomonas. Uhlinger \& White (1983) and Robertson \& Firestone (1992) selected strains on the basis of the mucoid aspect of bacterial colonies cultured on solid media. The former authors worked on Pseudomonas sp. isolated from soil and related EPS production to protection against desiccation, and the following authors studied the relationship between the physiological state and EPS production of Pseudomonas atlantica.

During the selection process the presence of pigmentation in all strains was detected. This was considered an important characteristic, since bacterial pigmentation in contaminated water has been attracting the attention of researchers, since it can give selective advantages which contribute to higher resistance and tolerance to microorganisms facing toxic substances (Nair et al., 1992; Arrage et al., 1993).

Lc and Lg strains excelled the other isolated strains in presenting Gram-positive pleomorphic cells arranged in clusters and, as Lb strain, presented better results with regard to the mucoid mode of colonies in E media and BHA 50\%. When cultured in liquid $\mathrm{E}$ medium, the three strains $(\mathrm{Lb}$, Lc and Lg) grew both with glucose and sucrose as carbon source, and a direct observation of the culture medium, during their cultivation, revealed a mucoid mode of growth in liquid media. This growth pattern both in solid and liquid media indicated a production of exopolysaccharide by bacteria, confirmed by the coloration with Alcian blue. Chan et al. (1984) observed the same growth pattern for Pseudomonas aeruginosa in liquid MVBM and BHI media and attributed this fact to the presence of cell embedded in a fiber EPS matrix, which promoted the adhesion between cells and cells to substrate (flask), forming microcolonies. 

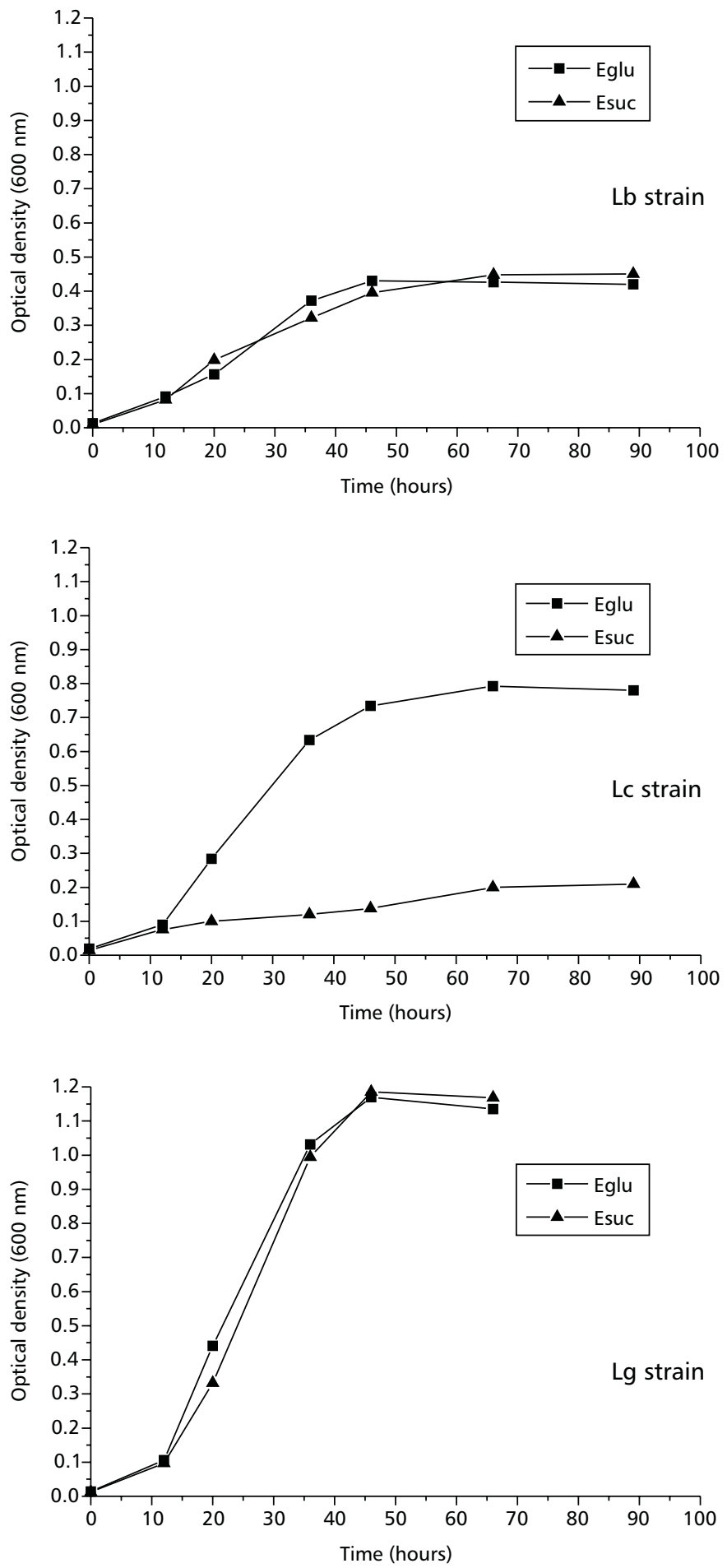

Fig. 1 - Growth of Lb, Lc and Lg strains with E medium supplemented with glucose (Eglu) and sucrose (Esuc). Growth under anaerobic conditions at $25^{\circ} \mathrm{C}$ in shaker at $100 \mathrm{rpm}$. 
TABLE 2

Visualization of EPS and expression of mucoidy state of bacterial strains isolated from polluted groundwater.

\begin{tabular}{|c|c|c|c|c|}
\hline \multirow{2}{*}{ Strains } & \multicolumn{2}{|c|}{ Expression of mucoidy state } & \multicolumn{2}{c|}{ EPS production } \\
\cline { 2 - 5 } & E medium & BHA 50\% medium & E medium \\
\cline { 2 - 5 } & \multicolumn{2}{|c|}{ Aerobiosis } & Anaerobiosis \\
\hline La & - & low & + & + \\
\hline Lb & low & high & + & + \\
\hline Lc & low & high & + & + \\
\hline Lf & - & - & + & + \\
\hline Lg & medium & - & + & + \\
\hline Lh & - & - & & + \\
\hline
\end{tabular}

In groundwater, the presence of polymers on the surface of bacterial cells was detected by some investigators (Ghiorse \& Balkwill, 1983; Hirsh \& Rades-Rohkohl, 1983) who related it to the increased adhesion to soil particles and to a higher probability of nutrient retention in oligotrophic environments. Recent studies found out that the property of accumulating nutrients from the environment of EPS - producing bacteria is due to the presence of different reactant groups in the structure of biofilm and thus the same can be used to remove different organic pollutants, such as agricultural chemicals (e.g. the herbicide diclofop methyl) (Wolfaardt et al., 1994; Wolfaardt et al., 1998) and metals from the environment (Shen et al., 1993).

This work shows that groundwater adjacent to the old controlled landfill in the City of São Carlos can be a potential source of microorganisms for studies related to environmental remediation in the cited area, and that the bacteria that produce exopolysaccharide were selected successfully. Among the latter, it is important to emphasize the selection of Gordonia polyisoprenivorans, a species recently described by Linos et al. (1999). G. polyisoprnivorans, as other taxa of suborder Corynebacterineae (which Lc strain belongs to), has an important role in bioremediation and biodegradation of environmental pollutants, in particular for the capability to degrade rubber (Linos et al., 1999).
Acknowledgments - R. Fusconi is grateful to CNPq for scholarship support.

\section{REFERENCES}

ARRAGE, A. A., PHELPS, T. J., BENOIT, R. E. \& WHITE, D. C., 1993, Survival of subsurface microorganisms exposed to UV radiation and hydrogen peroxide. Appl. Environ. Microbiol., 59: 3545-3550.

ATLAS, R. M., 1995, Bioremediation. C\& En., 3: 32-42.

BUTLER, B. J., BARBARO, S. E., CROCKER, F. H. \& MAYFIELD, C. I., 1997, Characterization of microbial populations of the Borden Aquifer. Geomicrobiol. J., 14: 253-268.

CLARK, J. B., MUNNECKE, D. M. \& JENNEMAN, G. E., 1981, In situ microbial enhancement of oil recovery. Devel. Ind. Microbiol., 22: 695-701.

CHAN, R., LAM, J. S. \& COSTERTON, J. W., 1984, Influence of culture conditions on expression of the mucoid mode of growth of Pseudomonas aeruginosa. J. Clin. Microbiol., 19: 8-1.

COSTERTON, J. W., 1985, The role of bacterial exopolysaccharides in nature and disease. Dev. Ind. Microbiol., 26: 249-261.

ELLERT, N., ROSS, S., MENDES, J. M. B. M. \& MARTIN, E., 1990, Mapeamento geofísico do lixão de São Carlos. 6ํㅡㄹ Congresso Brasileiro de Águas Subterrâneas, Porto Alegre, pp. 82-88.

FLIERMANS, C. B. \& BALKWILL, D. L., 1989, Microbial life in deep terrestrial subsurface. Bioscience, 39: 370-377.

FUSCONI, R. \& GODINHO, M. J. L., 1999, Bacteria and protozoa population in groundwater in a landfill area in São Carlos, SP. Rev. Microbiol., 30: 196-202. 
GHIORSE, W. C. \& BALKWILL, D. L., 1983, Enumeration and morphological characterization of bacteria indigenous to subsurface environments. Dev. Ind. Microbiol., 24: 213-224.

GIBERT, J., STANFORD, J. A., DOLE-OLIVIER, M.-J. \& WARD, J. V., 1994, Basic attributes of groundwater ecosystems and prospects for research. In: J. Gibert, D. L. Danielopol \& J. A. Stanford (eds.), Groundwater ecology. Academic Press, London.

GOUNOT, A. M., 1994, Microbial ecology of groundwaters. In: J. Gibert, D. L. Danielopol \& J. A. Stanford (eds.), Groundwater ecology. Academic Press, London.

HIRSCH, P. \& RADES-ROHKOHL, E., 1983, Microbial diversity in a groundwater aquifer in northern Germany. Develop. Ind. Microb., 24: 183-200.

JUNKINS, A. D. \& DOYLE, M. P., 1992, Demonstration of exopolysaccharide production by enterohemorrhagic $E s$ cherichia coli. Curr. Microbiol., 25: 9-17.

JURGENSEN, C. A., 1981, Caracterização preliminar, a nível de gênero, para bactérias anaeróbias predominantes em material clínico. Rev. Pat. Clin., 17: 74-77.

KÖLBEL-BOELKE, J., TIENKEN, B. \& NEHRKORN, A., 1988, Microbial communities in the satured groundwater environment I: methods of isolation and characterization of heterotrophic bacteria. Microb. Ecol., 16: 17-29.

LAPPIN-SCOTT, H. M. \& COSTERTON, J. W., 1992, Ultramicrobacteria and their biotechnological applications. Curr. Opin. Biotechnol., 3: 283-285.

LINOS, A., STEINBÜCHEL, A., SPRÖER, C. \& KROPPENSTEDT, R. M., 1999, Gordonia polyisoprenivorans sp. Nov., a rubber-degrading actinomycete isolated from an automobile tyre. Int. J. Syst. Bacteriol., 49: 1785-1791.

LINTON, J. D., 1990, The relationship between metabolite production and the growth efficiency of the production organism. FEMS Microbiol. Rev., 75: 1-18.

MURRAY, R. G. E., DOETSCH, R. N. \& ROBINOW, C. F., 1994, Determinative and cytological light microscopy. In: P. Gerhardt et al. (eds.), Manual of methods for general bacteriology. American Society for Microbiology Press, Washington.
NAIR, S., CHANDRAMOHAN, D. \& BHARATHI, B., 1992, Differential sensitivity of pigmented and non-pigmented marine bacteria to metals and atibiotics. Water Res., 26: 431-434.

ROBERTSON, E. B. \& FIRESTONE, M. K., 1992, Relationship between desiccation and exopolysaccharide production in a soil Pseudomonas sp. Appl. Environ. Microbiol., 58: 1284-1291.

SHEN, C. F., KOSARIC, N. \& BLASZCZYK, R., 1993, The effect of heavy metals ( $\mathrm{Ni}, \mathrm{Co}$ and $\mathrm{Fe}$ ) on anaerobic granules and their exracellular substance. Water. Res., 27: 25-33.

SMIBERT, R. M. \& KRIEG, N. R., 1994, Phenotipic characterization. In: P. Gerhardt et al. (eds.), Manual of methods for general bacteriology. American Society for Microbiology Press, Washington.

SUTHERLAND, I. W., 1990, Biotechnology of microbial exopolysaccharides. Cambridge University Press, Cambridge, $163 \mathrm{p}$.

UHLINGER, D. J. \& WHITE, D. C., 1983, Relationship between physiological status and formation of extracellular polysaccharide glycocalyx in Pseudomonas atlantica. Appl. Environ. Microbiol., 45: 64-70.

WOLFAARDT, G. M., LAWRENCE, J. R., HEADLEY, J. V. \& ROBARTS, R. D., 1994, Microbial exopolymers provide a mechanism for bioaccumulation of contaminants. Microb. Ecol., 27: 279-291.

WOLFAARDT, G. M., LAWRENCE, J. R., ROBARTS, R. D. \& CALDWELL, D. E., 1998, In situ characterization of biofilm exopolymers involved in the accumulation of chlorinated organics. Microb. Ecol., 35: 213-223.

ZHENG, M. \& KELLOGG, S. T., 1994, Analysis of bacterial populations in a basalt aquifer. Can J. Microbiol., 40: 944-954. 